\begin{tabular}{ll}
\hline 原 著 \\
\hline
\end{tabular}

\title{
看護婦の認知する共感の構造と過程
}

\author{
小 代 聖 香*
}

\section{Percieved Structure and Process of Empathy by Japanese Nurses}

\author{
Shodai Kiyoka \\ St.Luke's College of Nursing
}

\begin{abstract}
The concept of empathy is the key factor for undrestanding the object and contains the meanings of helping. This study aimed to inductively deliniate the structure and process of empathy in the patient-nurse relationship through the perception of nurses by using the methods of the participant observation and interview. The subjects of this study were 19 nurses in a medical unit of a private university hospital in Tokyo. The result of the study showed that 1) in the very first moment when a patient and a nurse met, the nurse percived attraction (aishou) toward the patient, 2) then the both began to disclosure private-self to the other (mutual openness), 3) which led the nurse to sympathize with the patient, 4) and to mutually confirm the feelings and responces to the other, 5) and finally reached the feelings of empathy which was perceived by the nurses that mutual feeling were transmitted and understood. If the empathy was once experienced, the nurses felt that the mutual relathionship tended to continue and deepen as the time passed. It has been emphasized in the literature that the helper in the empathetical relationship may feel as if he or she were the client but should not emotionally identify with the person. However, the result of this study indicates that the nurses experience the relationship as the strong feelings of identification with patients. It may occure due to he Japanese cultural context.
\end{abstract}

\section{要旨}

「共感」は，対象者を理解する上で鍵となる因子であり，援助的意味をもつていわれてい る. 本研究では; 看護婦の認知する看護婦一患者関係における共感のプロセスと，その構 成要素を, 参加観察法及び面接法によって㷌納的に導き出した. 対象者は, 東京都内の某 私立大学病院の 1 内科病棟の看護婦19名である.分析の結果, 共感は, まず「共感者(看護 婦)」と「被共感者(患者)」がいて，この 2 者が出合い，その初期の段階で「相性」といわれる 感覚が生じる.そしてお互いの私的自己をopenにする「相互open」さらに,「同情」が括こ 
り，お互いの気持ちや反応を「確認し合ら相互作用」をおこない，それを経て，気持ちが伝 わり通じたという「共感」を感じている，一旦共感が体験されると, 看護婦は, 患者との相 互関係が継続し, 時がたつにつれて深まっていくと感じている. 文献によると, 援助者は, 共感的関わりにおいては, あたかも対象者であるかのように感じながらも，決してその人 と情緒的に同一化すべきでないと強調している. しかしこの研究では, 看護婦は, 共感す る際患者との一体感を強く感じているといら結果がえられた。これは, 日本人の文化的心 理特性によるものであろう.

\section{I .はじめに}

看護は, 重要な治療的人間関係の過程であり, 看護婦と患者が共通の目的に向かって相互作用 し，共に㗢くプロセスであるといわれている1). そして，人間対人間の関係を確立することを通 して看護の目標が達成されるといわれている2). つまり, 看護婦の提供するケアが有効なものに なるためには，その看護婦と患者との間でつく りあげる人間関係が大きく影響するといえるだ ろう。

それでは援助的な看護婦一患者関係を成立さ せるためには何が必要なのであろらか. 援助が 人間的な意味での支えになるためには，心の交 流が大きな役割をし，交流の中でなされる人間 理解は援助を有効にするといわれている3)。 ま た，看護のプロセスは看護婦と患者が相互に理 解し合おらとするプロセスであるととらえられ ており ${ }^{4,5)}$,「理解する」といらことが援助的な 看護の重要な要素であると考えられるだろう.

相手を理解しようとするとき，人は相手の立 場に自分を置こうと努力し，その人が体験して いる世界をともに体験してみようとする．これ は, 「共感的理解」とよばれて扔り6〜8), 共感 は対象を理解する上での鍵となる因子であると いえるだろう，共感を通して対象者も，理解し てもらったことを基盤にして対象者自身の自己 洞察を深めることができるのである。このよう に，看護にとって「共感」といら概念は重要な 意味を持つ概念であると考えられる。

さて，「共感」といら概念は，1900年初頭美 学において用いられた概念であり ${ }^{9)}$, 自我の他 我認識といら意味が強かった。が，その後臨床 心理学者たちが用いるようになり, 感情的受容,
投射といら意味が強くなった ${ }^{10)}$. 看護の分野 に取り入れられたのは, 1960年代後半である. 借り物の概念であった「共感」は，看護の中で 次第にその見直しと適用が試みられ，いろいろ な測定用具を用いて操作化の方向に向かってい る.しかし，これらの測定用具を用いた共感の 研究は, 欧米で行われているものの, 日本にお いては取り入れられていない。日本では共感の 研究や11)，共感に類すると考穴られる「了解」 12)，「暗黙知」13,14）「甘光」15)などのテーマが 取り上げられ，看護者もこれらのテーマに対す る関心が高い。にもかかわらず共感という抽象 概念が操作化の方向に向かっていかないのはな ぜであろらか. 欧米に拈いて信頼性, 妥当性の 高い測定用具であっても, 日本という文化が, その導入を受け入れにくくしているのではない だろらか。

さて，日本の文化をみてみると，日本人はア メリカ人と比較して，コミュニケーションの性 質として，他人に知らせる自分の部分 (公的自 己)は比較的小さく, 他人に示さない部分(私的 自己)は比較的大きいというP.C. Barnlundの 指摘がある ${ }^{17}$ ) (図 I ). 又, 会田は,「日本人は 言葉(ロゴス)に否定的であり，相互理解のため には論理的な言葉は邪魔であるといら気持ちを 持っている.ささらに，ヨーロッパ人は相手を理 解するためには，その相手の体験を追体験しよ らとするが，日本人は察し，相手の身になって 考光る，それができるのは，自分の立場を白紙 状態におくからである.」ととらえている18). 又，土居は，日本人の文化的心理特性は「甘光」 であるとし，「甘光」は相手との一体感を求め ること，すなわち「同一化」ととらえている19).

このように, 日本人の対人関係や相互理解は 
日本

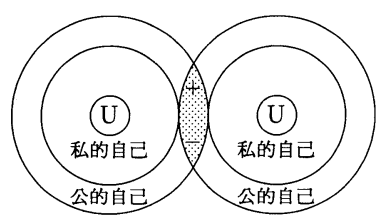

アメリカ

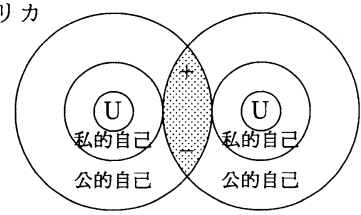

$\mathrm{U}$ : 無意識の領域を形成する心理的前提 や動機ほとんど探りえないすの 土：同意や不同意が起こることを示す

図 I . 個人間コミュニケーション

D.C. Barnlund 著, 西山 千訳

日本人の表現構造, p38, サイマル出 版会1973

欧米人に比べると自己を露出することが少なく， 言葉に対し否定的であり, 察するといらことが できる。さらに，相手との一体感を求めるとい ら特性をもっている，といえるだろう．看護婦 一患者関係といら対人関係において「共感」と いら相互理解に関するテーマを扱おうとすると き，このような文化的特質は大きく関わってく る因子であると考えられる。

本研究は, 日本に和ける看護婦一患者関係で いう「共感」とは実際にはどういう現象である のかを確認し，「共感」の概念と，その構成要 素を明確化することを目的とする。目標は, 現 場で働く看護婦が「共感」をどう認知している のかをあきらかにし，看護婦の認知する「共感」 の構成要素, 影響因子, プロセスを抽出し, 仮 説化することである.

\section{II. 文献検討}

\section{1.「共感」概念の看護への導入と既存研究}

「共感 (empathy)」という語は, もともと美 学の分野のT. Lipps が提唱した「感情移入（独・ Einf ühlung)」の英訳である. Lippsにおいて は, 自我の他我認識作用という意味が強かった 20).この「empathy」という概念を英語圏に 紹介したのは心理学者のG.W. Allportである 21). その後H.S. Sullivan ${ }^{22 \sim 24)}$, C. Rogers ${ }^{25)}$
等が頻繁に使い始めるようになるにしたがって， 感情的受容, あるいは投射という意味の注らが 強くなってきた。この考え方は, 看護の理論家 であるJ. Travelbee ${ }^{26)}$ やH.E. Peplau ${ }^{27) な と ゙ ~}$ の理論的基盤ともなっている. 借り物の概念と して看護に導入されて「共感」は徐々に看護状 況に適用する方向へと研究が進められてきてい $3^{28)}$. 概念導入の初期(1960年代末)L.T. Zderad pV.E. Ehmannは一般的な共感と臨床的, 専 門的な共感とを区別した.Zderadは「empathy」 を他者の存在を分け合らことによって他者と一 体化することとし29), Ehmannは, 我々の意 識を他者の中に導き入れることであり，それに よって患者を理解し, 患者の潜在力を促進する とのべている30). その後, E. Mansfield の精 神科看護婦の共感的コミュニケーションを促進 する行為についての研究 ${ }^{31)}$ や.J. Kalish, P.L. Rosendahl, E.L. LaMonica らの, 共感能力養 成, 評価といった教育的研究などがすすめられ $た^{32 \sim 36)}$. 又, S.L. Sparling, S.L. Jones ${ }^{37)}$, G.L. Forsythは, 共感能力に人口統計学的要 素がどら関るかについて研究している ${ }^{39)}$. こ のように，「共感」概念を操作化する方向にま で向かっているものの, 依然,「共感」概念の 定義, 構成要素, 発生のメカニズムやプロセス といった概念の枠組そのものは確定されている わけではない。

\section{2. 日本における共感の研究}

日本に和ける「共感」の研究は, ほとんどが エッセイの形をとるものや症例分析である. 「共感」は患者の理解や患者とのコミュニケー ションを発展させる上での重要な因子であると とらえられて㐨り,「共感」40 44)の他にも「わ かる」45,46),「理解」47,48), 「直感」49), 「感受性」 $50,51)$ ，「暗黙知」52)など「共感」に類似すると 考えられるような概念に注目している.しかし 研究といら形のものは少ない。

\section{3. 類似概念との比較}

「共感」という概念は，その本質が不明確な ため，類似した概念との区別が難しい。「共感」 に類する概念である「感情移入」,「同情」,「同 
感」,「同一化」,「投射」,「了解」,「受容」，と 「共感」とを比較検討し,「共感」概念の位置 付けを明らかにしてみたい。

「共感」は，「empathy」や「sympathy」 と訳され，これらの原語は，又「感情移入」 「同情」「同感」とも訳される53).「感情移入」 は，こちら側の感情状態が相手側に反映すると いらことで，「投射」に近い概念であろら54). 「同情」は相手へのあわれみであり，自分の感 情で相手を見るため, 認知は不正確で，「共感」 ほど援助的ではないといわれている。 これに対 し「共感」は「あたかも〜であるかのように」 であるから，分離性があり相手の認知が正確で， 意識的であるといわれている55)。

「投射」は，無意識的に自分の特性を他に帰 属する現実歪曲のプロセス56)，つまり，自分 の感情や思考が相手のものであると思ってしま らことである.

「同一化」は，相手の立場に立って，そこか ら出られない，無意識の模倣のプロセスである 57 60).

「了解」は，ひとの心の分かり方のひとつの 様式である. 単に理解し合らといらレベルをこ えて，その関係の中から何かが生み出されるよ らな可能性を持った理解のしかたである.この 「了解」という理解の仕方が共感的理解である というとらえかたもある61).

「受容」は，治療的技法のひとつととらえら れており，相手を受け入れ，本質において批判 しないこと62)，無条件に価值ある人間として 認めること63,64)，といわれている.

このようにみてみると, 類似概念との比較に おける重要な 1 つのポイントは, 同一性の保持 であり,「共感」は共感者の同一性が失われな いで，意識的になされるものととらえられてい る.しかし，日本の文献においては「共感」は， 自分も同じように感じること65), 同一のもの を体験することで同情, 共鳴し理解すること, 同一人物になりらる能力 ${ }^{66)}$ など，それを自覚 しているか自覚していないかは別にして，同一 化の性質が強いものとしてとらえられている.

\section{III. 研究方法}

本研究に打いては, 帰納的, 質的研究方法を 用いた。

\section{1. 帰納的, 質的研究方法を用いる根拠}

「共感」概念は，これまで，外側から見た定 義がなされてきた.が，共感している人はいっ たいどんな体験をしているのかといった，内的 な世界を見ることはなされていない，日本の看 護において, 共感的に理解することが重要な看 護ケアであるといらことが，長い間いわれつづ けていることであるにもかかわらず，共感する ときその人のなかでどんな事が括こっていて， どんな体験をしているのかといった方向から 「共感」を定義していくことがなされていない。 そこで, 本研究では, 内的世界から「共感」と いら概念を明らかにすることを試みた。そのた めには，事実に根ざしたデータから，その概念 を浮き彫りにしていくことが必要となる．した がって, 本研究に招いては現象(現にある状態, 経験的事象)をそのままとら光，そこから要素 を抽出し，その関係を見ることによって，概念 をあきらかにし，そして理論へと導いていく帰 納的, 質的研究方法を用いることが妥当である と考光， G rounded T heoryに基づいて研究を 進めていった. 具体的方法として参加観察法と 面接法を用いた 67 71)。

\section{2. 対 象}

東京都内の某私立大学付属病院の慢性疾患患 者中心の 1 内科病棟で働く看護婦を対象とした. その病棟で働く全看護婦数は29名であったが, その中から多様な年齢を取るために，年齢階層 別に看護婦を選択した. 29名中観察対象となっ た看護婦は17名，面接対象となった看護婦は， 観察対象の17名を含む19名である. 平均年齢は 24.5歳, 全員未婚の女性である.

\section{3. 期 間}

データ収集は, 昭和 60 年 8 月中旬から10月末 までの約 2 ヶ月半の期間で行った。 


\section{4. 方 法}

1) 研究の準備

本研究で用いた研究方法は，その測定用具が 研究者自身であるという点で, 収集したデータ やその分析にゆがみが生じる可能性が大きい場 合が多い，従って，本研究をすすめるにあたり， G rounded T heory 研究法の経験者である指導 者のもとで, 記述, 分析の訓練を受けた.

\section{2 ) 参加観察法}

本研究では, 研修看護婦として病棟に入り業 務を行う看護婦たちの近くにいて，彼女たちの 言動を見たり，時に患者へのケアの介助をした りといったかたちで観察を続けた。つまり，参 加者としての観察者の立場で看護婦と患者の関 わりを観察した。 その関わりの中で，「共感」 のおこる，あるいはそれに至らない場面の観察 をし, 観察したらその場を離れ, 忘れないらち に場面のメモを取った. 看護婦の行動や言葉で, その内容のわからない点や, 確認したい点につ いては, 後にその看護婦に話を聞き, データを 補強するといら作業を行った。メモはできるだ けその日のうちにフィールドノートとして詳細 飞記述し，分析した。データとして得た観察の 場面は34場面である。その観察場面を分析して いくうちに，同じような現象がいくつか見兑て きたので，その段階から面接法に切り替えていっ た.

3 ) 面接法

面接は, 観察した場面の記述分析をもとに作 成したopen-end の質問項目について行った.
基本的には，「いいかかわり」や「共感」の体 験談,「共感」の意味をどう思らか,「あう，あ わない患者」がいるか，それはどらいら患者か， なぞから質問していったが，面接も，観察之同 様に，面接に進めるらちに同じような傾向性が みえてくると(「理論的飽和状態」72))，それを もとに新たに質問内容を加えた．又観察した場 面で疑問に思ったことを確認した，面接時間は 1 人 30 分 1 時間半であった. 面接内容は，全 て看護婦の了承のもとにテープレコーダー録音 し，逐語で記述し分析した．分析しては次の面 接をするといらように，螺旋状に進めていった。 なお，この研究において得たデータの量は，B 4 版の用紙に616枚である.

\section{IV. 結 果}

観察，面接によって得たデータを分析した結 果, 看護婦が共感をどんな感情として認知して いるのかがみえてきたままた，看護婦が共感を 体験するに至った前後のプロセスがみえてきた．

看護婦は，共感を「心がスッと通った感じ」 「患者の気持ちが伝わった，感じた」「同じ気持 ちになった」といら感覚として認知している.

さて，抽出された要素は，「共感者(看護婦)」 「被共感者(患者)」「相性」「相互open」「同情」 「確認し合う相互作用」「共感」「共感後」であ る.さらに「共感」が抏こるときの環境因子， 状況因子として「閉ざされた場」「患者をとり まく人たちの協力的態度」が抽出された(図II).

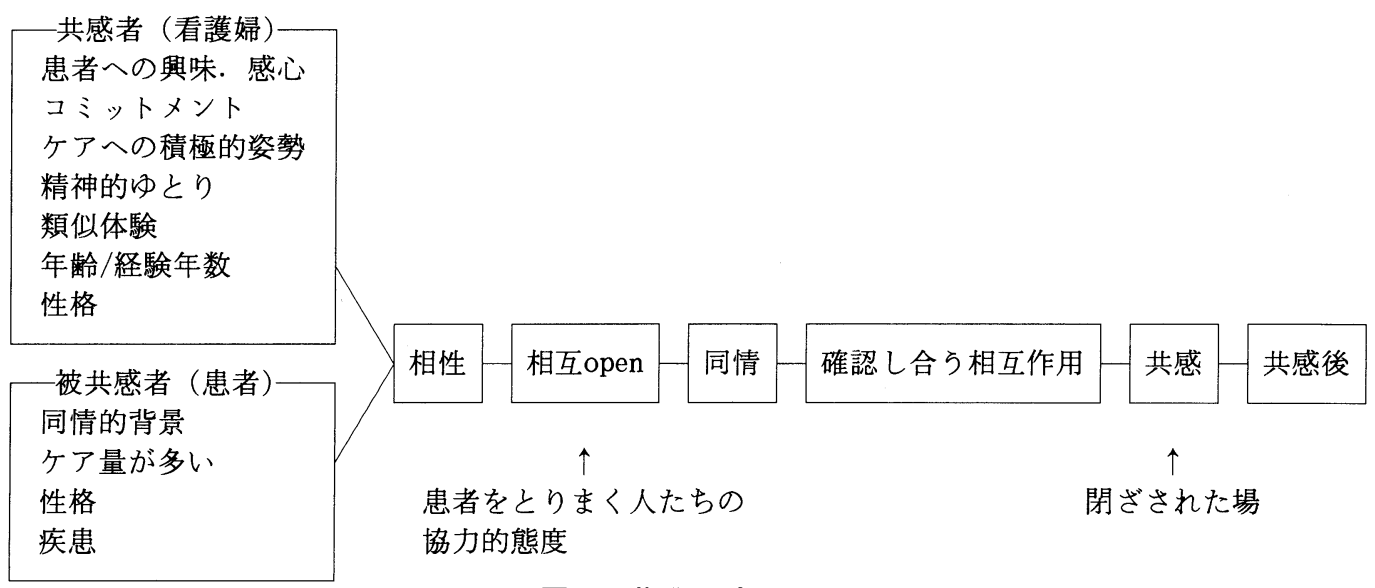

図 II．共感のプロセス 
以下に，これらの要素の属性についてそれぞれ 述べる.

\section{1. 共感者(看護婦)}

「共感」といら体験をするにあたって，共感 者である看護者のもつ特性が, より共感しやす かったり,そうでなかったりといった要因になっ ている、そのような看護婦の特質には，「患者 への興味, 関心」「コミットメント」「ケアへの 積極的姿勢」「精神的ゆとり」「類似体験」「年 齢」「性格」がある。以下に，これらひとつひ とつの特質について述べてみたい。

1 ）患者への興味, 関心

看護婦は，共感した患者について，「患者の 生き方にひかれる」「病棟内で浮いていて気に なる」と述べている，看護婦が患者の特性にひ かれたり，なにかしら気になる存在として受け 止めることが共感しやすい看護婦の 1 つの特質 である.

\section{2) コミットメント}

その患者が，自分の受け持ち患者である場合， 研究の症例である場合, 就職して初めてかかわっ た患者である場合は，最初からかなりの心構え と, 目的, 責任を持ってかかわりをもつ.

\section{3 ）ケアへの積極的姿勢}

患者を「常に受けとめようといら気持ちで接 している」とか，暴れる患者の寝衣の工夫をし て何度も作り代えているらちに，患者と近くなっ ていった体験が語られた. 患者のケアに対して 積極的に取り組む姿勢を持っていることも, 看 護婦が共感しやすくなる 1 つの特質である.

4 ) 精神的ゆとり

業務量が多く忙しいときや，個人的に悩みが あるときには，共感が起こりにくい， 1 年目の 看護婦の中には「自分の事で精一杯で, 他人の 事を理解する事ができない」「精神的に落ち着 いていないと患者の感情を受けつけなくなる」 と述べるものがいた. 看護婦が精神的なゆとり を持っていることが，共感しやすくなる 1 つの 特質である. しかし，忙しさが共感の妨げにな るものではなく，積極的努力で克服できるとい ら看護婦もいた。

5 ) 類似体験
看護婦が，過去にその患者と同じような体験 をしているということが，共感しやすくなる看 護婦の 1 つの特質である. この「類似体験」を 共感の要素としてあげている理論家もいる73).

\section{6 ) 年齢 $/$ 経験年数}

年齢については，これまでになされた研究で も, 共感の要素としてとらえられているが $74,75)$ ，どれも年齢の違いに有意差はないとい う結果が出ている. 今回の面接で, 経験の長い 看護婦に共感体験を語ってもらったところ, 比 較的若い時期の体験を出してきた. 経験年数 16 年目の看護婦は 5,6 年目のころ, 9 年の看護 婦は 2,3 年目のころ, 4,5 年の看護婦は 1 , 2 年目のころの例をあげている. 又, 就職して 半年の看護婦たちからも, 共感体験が語られて いる。

\section{7 ) 性格}

管理職の立場の看護婦に, どんな看護婦がよ り共感的だと思らか，と聞いてみたところ「相 手を受け入れられる素直さをもっている看護婦」 といら答えが得られた。面接対象となった看護 婦の中に 2 人, 共感がどらいうものなのかつか みにくいといら看護婦がいた. 彼女たちは, 自 分のことを「回転が鈍い」「問題意識がない」 「患者さんに深くはいっていけない」あるいは 「自分より若い人が上までいっている一自分が 惨め」「括ど抒どしてしまら」と評価するなど， 自尊感情が低い。どんな性格の看護婦が共感し やすいかという点については，看護婦あるいは 患者それぞれの性格というよりはむしろ，その 相互作用が重要であり, 後に述べる「相性」に かかわってくると考えられる。

\section{2. 被共感者（患者）}

それでは，看護婦が共感しやすい患者といら のがいるのであろらか. 本研究では看護婦は, ある特質を持った患者に，より共感しやすいと いら結果がえられた。この患者の特質は, 看護 婦から見た特質であり，「同情的背景」「ケア量 が多い」「性格」「疾患」である.

1) 同情的背景

患者の背景が同情的であるということは，看 護婦に強い関心を起こさせる，例えば，入院中 
に結婚した癌末期の若い女性患者や出稼ぎで上 京している男性患者に対して「かわいそう」 「同情する」「何とかしてあげたい」といら感情 を抱き，他の患者とは違った注目をしている。 看護婦は, 同情する患者に共感しやすい。

2 ) ケア量が多い

いわゆる，手のかかる患者に看護婦は共感し やすい，ケアの量が多いと，必然的により頻繁 に接近し注意を向ける. 身体的接触も多い. 看 護婦は，「苦労してベッドバスをやった患者は， 後がスムーズ」「ベッド上排泄の人のほうが, ポータブル便器で排泄した人よりも親しい気持 ちが強い」と述べ，又「それは患者もそらのよ らで『私の辛い時期につきあってくれた』とい ら気持ちが後々まで残っていくようだ」と述べ ている.

3 ) 性格

看護婦が，共感できるととらえる患者の性格 は，「ハキハキしている」「寛容」「素直」「お招 らか」「がまん強い」と表現されている。そし てこのよらな患者を自分と合う患者であるとと らえている。

\section{4 ) 疾患}

患者の疾患が生命にかかわらない場合のほう がいいかかわりができ，共感でさるといら看護 婦と, 疾患が重篤な場合のほらができるという 看護婦がいる. 前者は, 関わりの際緊張なくゆ とりがもてるから, あるいは，退院後手紙やあ いさつをもらい，いい評価や反応がもら觉るか らと述べている，逆に後者の場合は，同情する し，接する機会が多いからだと述べている。

以上, 共感が起こるときには, まず, 共感す る看護婦と共感される患者がいる。そしてその 看護婦と患者には共感しやすい特質がある, と のべてきた：それでは，そのような特質を持っ た看護婦と患者が出合って共感が起こるまで, どんなプロセスをたどるのであろうか.

\section{3. 相性}

看護婦は, 患者との出合いの初期の段階で 「うまが合う，合わない」という感情を抱く. これは, 直感的なものであり, 漠然と捕えられ ている、しかしながら，一般に「相性」といわ
れるよらなこの感覚は，以後の看護婦一患者関 係の方向性にかなり影響を及ぼしている。つま り，「相性がいい」と認知された患者とのかか わりは，「共感」へと発展しやすく「相性が悪 い」と認知されると，共感のプロセスの次の段 階に移っていきにくい。

看護婦が「合わない，苦手」ととらえる患者 は，以下の 4 タイプに分類できた.

(1)看護婦と患者の力バランスで, 患者のほうが 力が大きい患者. これは，「高飛車でプライ ドが高い」「インテリジェンスが高い」「おら へい」「鋭い言葉を投げかける」と表現され ている.このタイプをあげた看護婦は 8 名で ある・

(2)神経質・粘着タイプの患者.「しつこい」「訴 えが多い」「神経質」と看護婦が感じる患者 である．このタイプをあげた看護婦は 8 名で ある。

(3)反応がなく，進展しない患者・「はっきりし ない」「話していてもきりがなく，なかなか そこから踏み出せない」「反応がない」患者 である.このタイプをあげた看護婦は 4 名で ある。

(4)頑固な患者.「気難しい」「頑固」な患者であ る. このタイプをあげた看護婦は 3 名である. 以上のようなタイプの患者に対して「苦手, あわない」と感じると, 看護婦はその患者と のかかわりを避けたり，感情を抑えたりして しまらため, 以後のかかわりが発展していき にくくなってしまら。

さて反対に，看護婦が「らまがあら，相性が いい」ととらえた患者のタイプは, 以下の 5 タ イプに分類できた。

(1)気持ちや意見を素直に出す患者.「八キハキ している」「はっきり言う」「自分の考えを持っ ている」と看護婦がいう患者である.このタ イプをあげた看護婦は，12名である。

(2)成熟したパーソナリティをもっている患者 「ある程度看護婦側の状況をわかってくれる」 「人間として尊敬できる」「おおらか」な患者 である.このタイプをあげた看護婦は 4 名で ある・

(3)ケア量が多い患者. 看護婦はこのような患者 
に対して「やりがいがある」とのべ， 3 名の 看護婦がこのタイプをあげている.

(4)がまん強い患者. 看護婦はこのタイプの患者 に対して「応援してあげたくなる」という感 情を抱いている.このタイプをあげた看護婦 は 3 名である。

(5)看護婦自身と性格が似ている患者. このタイ プをあげた看護婦は 3 名である.

看護婦は,「あら, 相性がいい」と感じる患 者に対しては, そらでない患者に比べ, よりか かわりを深めていく傾向にあり,「共感」しや すいととらえている。では，「相性がいい」患 者とのかかわりは，どのように深まり共感へと 発展していくのであろらか。

\section{4. 相互open}

「相性がいい」と認知すると, 看護婦はその 患者を特別に気にかけるようになる，そして患 者をわかららとし，患者もわかってもら抢らと 努力する.拉互いわかり合抒らとして自分を出 す「相互open」はBarnlund ${ }^{76)}$ のいう「公的自 己, 私的自己」のらち「私的自己」つまり, 他 人にそらは示さない内面的な気持ち行動, 思考 の部分でopenであることは意味する。例えば， 「看護婦の立場でなく」「感じたことを素直にい う」「患者の娘のよらにとらえてくれるとやり やすい」「プライベートなことを言う」といら ように，看護婦といら公的自己としてのかかわ りではなく，個として私的な部分をopenにし て接するということである，そして，患者もプ ライベートな部分を任せたり，辛い気持ちを打 ち明けたりして，相互にopenになることでお 互いに特別なかかわりであるという意識を引き 起こす.このようなかかわりを持つようになる と, ある時期看護婦は患者に対し「同情」する といらことが抗こる。

\section{5. 同 情}

これまで，看護婦は患者に何となくひかれ気 になり, 相性のいい患者と認知し接近し, 相互 にopenにかかわりはじめる，といらプロセス をたどると述べてきた，その際，患者の状態が かなり切迫していたり, 苦しい辛い時期であっ
たりすると，その辛い時期につきあった，体験 を分かちあったということが，看護婦にとって はさらにかかわりを深める大きな要因になる. この時期看護婦は,「かわいそう」「なんとかし てあげたい」「助けてあげたい」といら気持ち を抱く。これは, 「同情」という概念に相当す るであろう。

\section{6. 確認し合う相互作用}

このように関係が進んでいくと, 看護婦と患 者はお互いを肯定的に認めあうようになる。例 えば，患者が看護婦に「一緒に話をしていると ストレスが解消される」「看護婦はこわいとい らイメージがあったけど全然違う」と伝える. また, いつもは表情の堅い患者がある看護婦に だけは穏やかに対応し, て談を言うと, その看 護婦もその患者に注目し, 気にかけ何度も訪室 するようになる. そして, 頻回な接触のうちに 看護婦は患者のパターンに慣れ, 看護婦と患者 は, お互いの思いを「確認し合う相互作用」を 行らようになる.そしてこのような相互作用を 行ららちに, ある瞬間看護婦は, 患者の気持ち が通じた，伝わった，感じ取ったという感覚を 体験している. この感覚が，「共感」であると 看護婦はとらえている.

\section{7. 共 感}

看護婦は共感体験を「娘になったみたい」 「(その患者の死に際し)そこにいられなかった」 「身内みたい」「病気が憎らしい, 本当に悲しかっ た，くやしかった」と表現している. 患者と共 に涙を流すなど, 患者と一緒に摇れ, 同一化し ている.が，1人の看護婦は，「客観性をもっ て看護婦の立場として患者とかかわっていける ようになると共感ができる」と述べていた，共 感の起こるきっかけは，例えば「うれしそうな 表情」「大きな声」「涙を流す」というょうに， 患者がいつにない表現や反応をしたり, 内面が 吐露されたときである，そのとき看護婦は， 「そらだったのか」「今まではわかってあげてな かった」と気付き，「患者の気持ちが伝わった， 感じた」「心がスッと通ったような感じ」「らま く伝わって返ってくる」「ツーカーである」と 
いう感覚を覚光，「気持ちがすっきりする」「話 してよかったといら満足感」「気持ちがワクワ クする」という感じを持つ. 看護婦は患者の気 持ちに気付き，患者の内的世界を体感する。

\section{8. 共感後}

さて，共感が起こった後，看護婦と患者には 変化が起こる，看護婦は，共感を契機にその患 者への関心がますます高まり，接近し積極的に かかわりを持つようになる.看護婦としてのア イデンティティも強化され，「看護婦として頑 張っていこらといら気になった」というように, 満足感を感じ，看護婦として働く動機付けにな るでき事としてとらえられる。そして共感体験 をした看護婦と患者の関係性は維持される。

\section{9. 共感の環境因子・状況因子}

これまで共感が起こるプロセスについてみて きた。本研究では，共感が抢こるにあたってそ の場の環境や状況が影響しているといらことが わかった．以下に，共感が生じやすい環境因子， 状況因子について述べてみたい。

1) 閉ざされた場

共感が招こるのに，その場が物理的に「閉 ざされた場」，すなわち第三者が入って来る 可能性がなく，看護婦と患者だけで共有する 場である，ということが共感の生じやすい環 境因子となる.

2 ）患者をとりまく人たちの協力的態度

医療者や家族など，患者をとりまく人たち が協力的で，いい関係のチームが組めたこと が，患者とのいいかかわり，共感を生じる 1 つの状況因子となる.

以上のよらに抽出してきた「共感」のプロセ スの構造及びその要素のいくつかについては, 共感にいたらなかったかかわりについてのデー タを分析することによって，つまり逆の視点か ら, 確かにその要素が「共感」の要素であると いらことが確認できた。しかしながら，このプ 口セスは必ず，相性 $\rightarrow$ 相互open $\rightarrow$ 同情 $\rightarrow$ 確認 乙合う相互作用 $\rightarrow$ 共感 $\rightarrow$ 共感後という順序で起 こるといらわけではない，例えば，プロセスを 経ずに共感が起こったり，共感から同情が起こっ
たり，といらようにこれら共感プロセスの各要 素は一方向で進んでいくとは限らない.

\section{V. 考察}

看護の分野において，看護婦一患者関係にとっ て重要であるとされ，また頻繁に用いられる 「共感」が臨床の場で働く看護婦たちにとって, とらえにくい概念であるといらことは共感体験 を語るときに，言語化することが難しかったり， 定義として述べたことと体験として述べたこと とのくい違いがあることなどからわかる．この 「共感」概念の不明確さといらのは，「共感」 という現象が「パトスの知」つまり身体的一体 性感覚的な知によってとらえられるものであり, 総合的, 直観的な「臨床の知」によって “感じ る”ものであるからだろらと考える。「臨床の 知」はこれまでの科学概念からはみだした学問, 対象との身体的な相互作用が理論そのものにとっ て決定的に重要な諸学問のらちにあらわれるも のといわれている。まさに看護学がそれにあた ると考学られるが，対象と相互主体的かつ相互 行為的にコミットし，いきいきとした関係や交 流を保つという特徵を持つものである. そして， 五感(諸感覚)の統合された知であるからこそ ${ }^{77}$ )，「共感」それ自体についての感覚を語るとき に，言語化しにくいという看護婦が多かったの であろう。

この臨床の知に拈いて最も良くあらわされる といわれるものがM. Polanyiのいら「暗黙知」 である. Polanyiは，「我々は，語ることがで きるより多くのことを知ることがでさる」と述 べ，知ることが言語的明示化をこえた可能性を もっていることを認めている。そして，この知 り方はある事物の中に「潜入する」ことによる のであり，この「潜入」あるいは「感情移入」 が人間を理解するのに適用された「暗黙知」の 1 形式である，と述べている. 更に，この潜入 の機能は, 内面化であり, 一体化であるとして いる ${ }^{78)}$.

共感するといらことは, 対象を理解するため の潜入であり，看護婦は，患者とのかかわりに おいて経験するあらゆる事象を統合し，暗黙的 
に知るということを体験しているのではないだ ろらか。

今回の研究でテーマとしてきた「共感」とい う概念は，まさにこの「暗黙知」によってとら えられる性質のものであろら，それは客観性を 持ち, 証明, 実証や一般化のできるようなもの ではなく，主観的で個別的なもの，つまり「認 知」によるものであり，したがって䚻納的プロ セスによって，個別的なものの中からパターン を見いだし，要素を発見してきたのである.

さて，そのような共感の体験は，看護婦にとっ ていいかかわりの体験であり，仕事の満足感を 引き起こし動機づけを強めるが，それは数少な い貴重な体験であるようだ.

今回の研究で興味を引いた結果のひとつに 「相性」がある.これは看護婦と患者の力バラ ンスと大さくかかわっている，すなわち，看護 婦は, 患者のほうが力が大きいと感じる患者に 対して「合わない，苦手」と認知している，逆 に「合う, 相性がいい」という認知は, 看護婦 のほうが力が大きい，あるいは力が等しいと感 じる場合である。

そこで，この「カバランス」の持つ意味につ いて考えてみたい. カバランスが，患者の汪う が力が大きいとき看護婦は, 患者から看護婦自 身のegoを脅かされる体験をするのではないだ ろらか. Freudは, egoが処理できない危機に 対して示す反応は「不安」であるとしているが 79,80), 患者の力が大きいことによって看護婦 のego がその力に対応できないような危険な状 況となり，押さえつけられる，そして「不安」 な状況を引き起こすと考兄られる。ささてSullivan は, 価值を認められ, 尊敬されるといった感覚 としての個人的安全保障感に対するあらゆる脅 威が「不安」を生じさせると述べている ${ }^{81)}$.

看護婦は, パワーの強い患者に出会い, 調和的 でない葛藤関係が生じると, 安全欠如感による 不安が起こってくるのであろうと考えられる. さて，「不安」がおこると「防衛機制」が働く. 看護婦は，患者によって脅かされるegoを守る ために感情を抑圧するなど，いろいろな形で防 衛しているのではないだろらか.この防衛のた めに, 看護婦と患者の相互作用が妨げられるこ
とになるようである。したがって教育や実践の 場で患者とのかかわりをむやみに押し進めるこ とは，看護婦のegoをますます脅かすことにな りかねないので避けなければならず，そこに何 らかのサポートが必要である，と考えられる。

さて，ここで「相性」と「カバランス」の関 係について見てみたい.Blauは「相性 (mutual attraction)」は結びつきを発展させる基礎, 友好的連帯感の基礎であるととらえ，さらに， 地位競争, すなわち力の競争といらものは, 関 係の中に重圧感を引き起こすと述べている ${ }^{82}$. 「相性」と「カバランス」は人の結び付きを発 展させることにかかわる重要な因子であり， 「力が等しい」といら認知は,「相性がいい」と いう認知を引き起こし，そのことによって結び 付きが深まっていく，と考えられる．したがっ て，看護婦あるいは患者のどちらかの力が大き いといら関係からは，共感が生じにくいといえ るのではないだろらか。

さて，援助的な共感に関する従来の文献にお いては，客観性といらことが重視されている 83 86). つまり共感者自身がその主体性を失わ ないといらことであるが，本研究に拈いては， かなり主観的で，一体感の強いものとして共感 は体験されているといら結果が得られた. 土居 は，日本人の心性を特徵づけるものは「甘え」 であるとのべ，この「甘光」が相手との一体感 を求めるもの, Freudのいら「同一化」と同じ ものであることを指摘している ${ }^{87,88)}$. このよ らに，相手と同一化し，取り込むことが文化的 心理特性である日本人ゆえに，共感体験は，よ り同一化, 一体化の性質の強いものであるのか もしれない.

\section{VI. 研究の限界と今後の課題}

以下に, この研究の限界をあげ，その限界を ふま兄て今後の研究を展望してみたい.

(1)本研究は，帰納的，質的方法を用いたわけだ が，データ収集期間が 2 ヶ月半であり，抽出 された各要素とその関係について十分明らか にするためには，期間が短いと思われる.

(2)前述のように, 研究者は参加観察法のスーパー 
ビジョンを受け, その信頼性を高める努力を しているが，ゆがみが生じる可能性は否定で きない。

(3)研究対象者が, 平均年齢24.5歳, 全員未婚で あることなど，偏りがある。

(4)「共感」の構造とプロセスにおいて抽出され た各要素は, 看護婦及び研究者の認知による ものであり，患者の認知が含まれていない。 したがって，患者にとって共感された体験と して認知されたかどらかは明らかでない。

以上の限界をふま充, 今後は, 看護婦と患者 の認知の対比の研究がなされれば,「共感」概 念やその現象, 共感体験の看護婦, 患者相互に とっての意味がより明確になるであろう。また， 看護婦の人口統計学的データとの関連による研 究や, 環境因子, 状況因子についてを含めて, さらに帰納的に研究を進め, その結果を演繹的 に検証するといった研究が望まれる.

\section{VII. 結 論}

本研究においては,「共感」概念を臨床の場 での現象と, 看護婦の認知からとらえてみた.

「共感」のプロセスの構成要素とその構造は, 以下の通りである.

\section{1.「共感」のプロセスとその要素}

(1)共感にいたるためには「共感者である看護婦」 と「被共感者である患者」がいて，それぞれ にその特質がある. 看護婦側の特質は(1)患者 への興味・関心, (2)コミットメント, (3)ケア への積極的姿勢, (4)精神的ゆとり, (5)類似体 験，(6)年齢，(7)性格である.患者側の特質は (1)同情的背景, (2)ケア量が多い, (3)性格, (4) 疾患である。

(2)共感者(看護婦) と被共感者(患者)が出会い, その初期の段階で「相性」の認知がおこる.

(3)看護婦と患者が私的自己をopen にしあら 「相互open」が括こる.

(4)看護婦に「同情」といわれる感情がおこる.

(5)長いかかわりや頻回な接触の中で, 看護婦と 患者は相互の思いを「確認し合う相互作用」 をおこなら。
(6)このようなプロセスの中で「共感」がおこる.

(7)「共感後」看護婦と患者の関係性は維持され る.

2. 共感がおこるためには，その場が物理的に 「閉ざされた場」であることが，ひとつの環境 因子となる。

3. 共感がおこるためには, 家族や医師など 「患者をとりまく人たちの協力的態度」がひと つの状況因子となる。

\section{謝辞}

本研究を行うにあたり，ご指導いただきました 聖路加看護大学の南裕子教授, そして, ご協力い ただきました病院の総婦長, 副総婦長, 病棟婦長, はじめ看護婦の皆様に心より感謝いたします.

\section{引用・参考文献}

1) H.E. Peplau, 稲田他訳 : 人間関係の看護論, 医学書院, 1973.

2) J. Travelbee, 長谷川浩他訳 : 人間対人間の 看護, 医学書院, 1977.

3）都留春夫：病者のこころの働き, 医学書院, 1975.

4) 湯槇ます編 : 系統看護学講座10看護学総論, 294, 医学書院, 1979.

5）金子光編：系統看護学講座 20 成人看護学 $X$ 精 神疾患患者の看護, 43, 医学書院, 1981.

6) 前掲書 3,128 .

7) 前掲書 $5,40-41$.

8) 前掲書 3,132 .

9）守屋淳 : 共感の研究一共感者の世界に定位し て一, 東京大学大学院教育学研究科修士学位 論文, 11, 1983年度.

10）北村晴朗監修: 心理学小辞典, 48 , 協同出版, 1978.

11）前掲書 3

12）黒丸正四郎, 大段智亮: 患者の心理, 創元社, 1984.

13） M. Polanyi, 佐藤敬三訳 : 暗黙知の次元一 言語から非言語へ一, 紀伊國屋書店, 1984 .

14）中村雄二郎：術語集, 岩波書店, 1984 . 
15）土居健郎：「甘光」の構造, 弘文堂, 1971.

16）大橋秀夫：甘只の弁証法, 土居健郎教授還暦 記念論文集刊行会編, 臨床精神医学論集, 星 和書店, 1980 .

17）Dean C. Barnlund，西山千訳：日本人の表 現構造一ことば.しぐさ.カルチュアー, サ イマル出版会, 1973.

18）会田雄次: 日本人の美意識構造一風土. 歴史. 社会一, 122-126, 講談社, 1973.

19）前掲書 15 .

20）前揭書 9 .

21）Allport. G.W, 詫間武俊, 青木孝悦他訳 : パーソナリティ一心理学的解釈-453-455, 新曜社, 1982.

22) Sullivan. H.S, 中井久夫, 山口隆訳 : 現代 精神医学の概念， 26-28， みすず書房， 1984.

23) Sullivan. H.S, Helen. S.P, Mary. L.G ed: The Interpersonal Theory of Psychiatry, 41-45, W.W. Norton \& Company INC 1953.

24） A.H.チャプマン，作田勉監訳：サリウァン 治療技法入門，星和書店， 1981 .

25）鼻瀬稔編訳：人間関係論，ロジャース全集 6 , 岩崎学術出版社, 1967.

26）前揭書 2 .

27）前掲書 1 .

28) B. Hoeffer, S. Murphy: The Unfinished Task; Development of Nursing Theory for Psychiatric and Mental Health Nursing practice, Journal of Psychosocial Nursing and Mental Health Services, 20.12, 8-14, 1982.

29) Zderad L.T: Empathic Nursing-Realization of a Human Capacity - , Nursing Clinics of Nourth America, 4.4, 655-662, 1969.

30) Ehmann V.E: Empathy-its origine, characteristics and process-, Perspective in Psychiatric Care, 9.2, 72-80, 1981.

31) E. Mansfield: Empathy-Concept and Identified Psychiatric Nursing Behavior, Nursing Research, 22.6, 525-530, 1973.

32) B.J. Alish: An Experiment in the Development of Empathy in Nursing Student, Nursing Research, 20.3, 202-211, 1971.

33) P.L. Rosendahl: Effectiveness of Empathy;
Nonprossessive Warmth and Genuineness of Self-Actualization of Nursing Students, Nursing Research, 22.3, 253-257, 1973.

34) E.L. LaMonica, et al: Empathy Training as the Major Thrust of a Staff Development Program, Nursinf Research, 25.6, 447-451, 1976.

35) E.L. LaManica, et al: Empathy Training, Nursing Mirror, 8.25, 22-25, 1977.

36) E.L. LaMonica: Empathy can be Learned, Nurse Educator, 8.2, 19-23, 1983.

37) Sparling S.L, Jones S.L: Setting; a contextual variable associated with empathy, Journal of Psychosocial Nursing and Mental Health Services, 15.4, 9-12, 1977.

38) Forsyth G.L: Exploration of Empathy in Nurse-Client Interaction, Advance in Nursing Science, 1.2, 53-61, 1979.

39) Forsyth G.L: Analysis of the Concept of Empathy-Illustration of one Approach, Advances in Nursing Science, 2.2, 33-42, 1980.

40）大段智亮：“理解する”ことについて, 看護 学雑誌, 38.10-11, 1088-1095, 1974.

41）岸 信行：「共感」と「言葉」, 看護展望, 3.11, 961-969, 1978.

42）斎藤美律子：Empathic Communicator とし ての看護婦，看護展望， 7.4, 316-320, 1982.

43）都留春夫 : 共感的理解, 総合看護, $55-68,1974$.

44）水野芳子：共感的理解の啓発をめざした実習 指導の試み, 看護展望, 6.10,83-91, 1981.

45）上野赢，“知る”と“わかる”：看護学雑 誌, 40.5, 513-516, 1976.

46）山口絢子, わかること. 知ることの周辺, 看 護, $32.8,20-25,1980$.

47）八谷量子：理解するといらこと一いま看護に 求められるもの一, 看護教育, 8, 450-453, 1983 .

48）鈴木信子：とら直されてきた “人間理解” についての一考察, 看護教育, 20.9, 539-542, 1979.

49）富田幾枝. 川島みどり. 藤村龍子. 南裕子： 「『ふれる』ことの哲学をめぐって」（ディス カッション), ナースステーション, 15.1, 96-111, 1985. 
50）近森芙美子：看護の表現としての感性の記述, 看護, $32.1,29-37,1980$.

51）野川とも江，感受性一その場でふみとどまる 力, 看護, $32.9,12-21,1980$.

52）南裕子, プライバシーと情報交換, 看護 $\mathrm{MOOK}$ 看護とコミュニケーション, 89-93, 金原出 版, 1986.

53）前掲書 9 .

54）春木豊. 岩下豊彦編著：共感の心理学一人間 関係の基礎一, 川島書店, 1981 .

55) Kalish B.J: What is Empathy?, American Journal of Nursing , 73.9, 1548-1552, 1973.

56) 前掲書 $2,220-223$.

57）前揭書 54,84 .

58）前掲書 $2 ， 220-223$.

59）前掲書 30 .

60）前掲書 55 .

61）前掲書 12 .

62) Joyce Samhamer Hays, Kenneth H. Larson, 日本赤十字社医療センタ一看護研究会訳 : 看 護実践と言葉一患者との相互作用, メヂカル フレンド社, 16-17, 1976.

63）前掲書 6, 6-7.

64）Mary G. Connolly, 稲田八重子他訳, 外口 玉子編：患者にとって受容とは何か, 患者の 理解一看護婦. 患者関係の展開の中で一, 現 代社, 167-183，1981.

65）エンクロペディア看護辞典, 広川書店, 288 , 1984.

66) 佐藤壹三他, 最新看護学全集 20 精神科看護学, メヂカルフレンド社, 158-160, 1982.

67) Denisr Polit. Bernadette Hungler: Nursing Research, 110-111, J.B.Lippin cott Co, 1983.

68) Barbara J. Stevens, 中西睦子. 雨宮悦子訳：
看護理論の理解のために, メヂカルサイエン スインターナショナル, 298-301, 1982.

69) Barney G. Glaser, Anselm L. Strauss: The Discovery of Grounded Theory, 3-6, Aldine Publishing Co, 1979.

70) L. Schatzman. A.L.Strauss, Field Researchstrategies for a natural sociology - , 1-17, Prentice Hall INC, 1973.

71) H.S. Willson, S.Y. Fagerhaugh : 参加観察 法研究会編, 特集: 看護研究における参加観 察法, 看護研究, $15.3,50-54,1982$.

72) 前掲書 69,70 .

73）前揭書 $2,203-204$.

74）前掲書 38 .

75）前掲書 39 .

76) 前揭書 17 .

77）前揭書 14 .

78）前揭書 13 .

79) C. Brenner, 山根常男訳 : 精神分析の理論, 43-44, 誠信書房, 1981.

80）土居健郎, 精神分析と精神病理 41-42, 83, 医学書院, 1982.

81) H.S. Sullivan, 中井久夫他訳 : 精神医学の 臨床研究 13-21, 67-70,102-106, みすず書 房, 1983.

82) P.M. Blau, Exchange and Power in Social Life, 33-59, John wiley \& Son's INC, 1967.

83）前揭書 30 .

84）前掲書 31 .

85）前揭書 40 .

86）前掲書 2 .

87) 前揭書 15 .

88）前掲書 80 . 